\title{
Audio Description, Rhetoric and Multimodality
}

\author{
Cristina Álvarez de Morales \\ Facultad de Traducción e Interpretación, Universidad de Granada, Spain \\ Email: cristinaalvarez@ugr.es
}

\begin{abstract}
This paper constitutes a theoretical reflection within the Project AMATRA of the University of Granada (Spain), part of the European Project Technological on-line framework to integrate the work flow of audiovisual accessible translation. We also are member of the Project PRA2 which is oriented towards creating a technological website platform open to any user, where people, regardless of the functional characteristics, can interact with any audiovisual resources. In the paper, we present the audio descriptive text as a new modern discourse, a coherent oral text and a speech act according to the five phases of Quintilian Rhetoric: inventio, dispositio, elocutio, memoria and actio. We also offer examples of the main tropes and figures that ornament the audio descriptive text and make it a rhetorical discourse.
\end{abstract}

Index Terms - audio description, inventio, dispositio, elocutio, actio, rhetoric discourse

\section{INTRODUCTION}

AMATRA is a translation research group of the University of Granada with a theoretical interest in Access to Knowledge, Multimodality and Translation training. This interest led us to create a data base of films with Spanish audio description (AD) in order to analyze, through Multimodal Corpus Linguistics methods, the characteristics of Spanish AD. Results from this analysis have a professional and a didactic application. They serve the double purpose of being the basis to carry out $\mathrm{AD}$ reception experiments that may contribute to the improvement of existing $\mathrm{AD}$ guidelines, and a valuable set of reference materials for $\mathrm{AD}$ training, $\mathrm{AD}$ training teaching, as well as for $\mathrm{AD}$ professionals.

This paper constitutes a theoretical reflection within the Project AMATRA oriented towards creating a technological website platform open to any user, where people, regardless of the functional characteristics, can interact with any audiovisual resources. In the paper, we present the audio descriptive text as a new modern discourse, a coherent oral text and a speech act according to the five phases of Quintilian Rhetoric: inventio, dispositio, elocutio, memoria and actio. We also offer examples of the main tropes and figures that ornament the audio descriptive text and make it a rhetorical discourse.

During the $21^{\text {st }}$ century, we find that we are immersed in multiple and multicultural thought and thus we could speak of a new foundation for academic knowledge that uses the studies on the audio descriptive text as the basis of the complex theory of discourse.

The audio descriptive text makes sense only within a singular society; if Rhetoric was born in the polis, with democracy as the frontier, Audio description can be considered within a social institution: the blind community. It is born into a society able to admit social exclusion as an element of social integration. If Rhetoric seeks to build rhetorical discourses to convince the audience concerning solutions to civil and political problems, the audio descriptive text builds a text to bring artistic discourse closer to the blind audience.

\section{RHETORIC AND AUDIO DESCRIPTION (AD)}

We know that Rhetoric is an art that teaches citizens to speak in public and it defends them by giving them the ability to say anything they wish without being offensive with their words. The orator can create a world faithful to reality, a world with a vision of the reality most adapted to the audience.

However, there is a mismatch between the real world and the "world" that we apprehend, think about, structure, or try to explain to the others. Therefore, we do not transmit to the other people that the real things are really are there, but rather they appear symbolized by the language, which enables us to build true discourse. As is well known, reality cannot be expressed or thought about only with words.

In this sense, Rhetoric is an essential perspective to persuade listeners, who receive the text depending on different communicative situations, sometimes completely opposed to the sensitive world of blind people. Therefore, in this paper, we contend that rhetorical discourse and $\mathrm{AD}$ can be, and in fact must be, understood as a real act of communication. However, it is a real act of speech also because it makes it possible for the audio descriptive text to be understood as rhetorical discourse, a coherent and functional text.

In this sense, it is important for the audio describer to be conscious of using language in order to build persuasive speech - that is, "attractive, convincing, and provocative worlds"-because these resulting discourses, these audio descriptive scripts, try to win followers: blind people completely able to share the feelings and opinions created by the social establishment. 
In the same way as traditional Rhetoric acted at the beginning of the history of literature, AD starts to be considered as an art: the art of creating coherent discourses using the same ornaments that the Rhetoric used.

Rhetoric does not in fact need to know the reality of things because it is a sort of artisan of persuasion. It presupposes the teaching of languages and literature from the orator based on many meditative readings and a sort of familiarity with poets and stylists from everywhere. Something similar occurs with $\mathrm{AD}$, because we consider it to be a technique (tekné). As a new rhetorical discourse, it uses the prior knowledge of the audio describer, new materials to remake the audio descriptive script in order to move the sensitive world of the blind people.

Thus, it could be said that the art of AD, if we understand that the audio descriptive text is an artistic text, in a lotmanian way, as Álvarez de Morales (2010) argues, recovers part of the essence of Quintilian Rhetoric, because its matter is built by all the themes and plots used by the audio describer who is interested in collecting, from the text prepared by himself/herself, all the particular elements which are part of the plot and genre treated in the film.

If the orators had to use their language taking advantage of their own text, and combining their intelligence with the emotional effect and the vivacity of the images of the recreated world, the audio describers, based on the oratory exercises of eloquence, will be able to write their scripts. They will perform this task based on the units of meaning that are part of the textual "corpus" able to serve as a channel of information between the world who can see and those who cannot.

As is well known, Rhetoric, step by step, and throughout the history, started to open a path and entered new fields of knowledge such as the Literature, Hermeneutics, or Aesthetics, which were the last disciplines to be influenced by the art of persuasion. During the $18^{\text {th }}$ and $19^{\text {th }}$ century, Rhetoric was open to the studies dedicated to Speech Acts and to Communication. Hence, Rhetoric was not equivalent to padding, affectiveness, or sophistication but it implied the art of organizing language from the main five oratory functions studied and defined by Quintilian: inventio, dispositio, elocutio, memory and actio. Four of these appear clearly in the audio descriptive script (but the memory, because the audio descriptive script is expressed but not memorized, only in the case of the AD of the theatre).

\section{AUdio DESCRIPTION: A NEW SPEECH ACT}

Austin and Searle were the creators of the Theory of the Speech Act, and this Theory contends that to speak is to make a speech act, considering the context as one of the most important parts of the script and (apart from the meanings) and considering also the illocutionary force ${ }^{1}$ that must be interpreted taking into account the totality of the speech act. In sum, in the speech act, we must interpret the semantic meaning of the words used by the speakers, interpreted as a pragmatic meaning, which is the same meaning as audio describers use when creating their text susceptible to being divided into many units of meanings.

Tropes and figures of diction and thought are born from the illocutionary act of speech, considering the illocutionary value as a true one. Thus, tropes such as metaphor, metonymy, hyperbole and irony, or figures of diction and thought are located in a certain situation, in a context, in a speech act; taking into account the importance of the relationship between the speaker and the listener, they result from the speaker's intention in exhorting the listener. In this sense, we should remember Austin's (1962) assertion: "The speech act will be successful if the circumstances that the words expressed are appropriate somehow" (p.49). The same applies to the audiodescriptive text because we can locate in it the tropes and figures that confer the audiodescriptive text an illocutionary character, its essence of a speech act. One example of this situation is the analysis of some audiodescriptive scripts of different films tagged throughout the software TAGGETTI used for the members of AMATRA Project.

\footnotetext{
${ }^{1}$ Illocutionary force: what words do as carriers of the speaker's intention.
} 


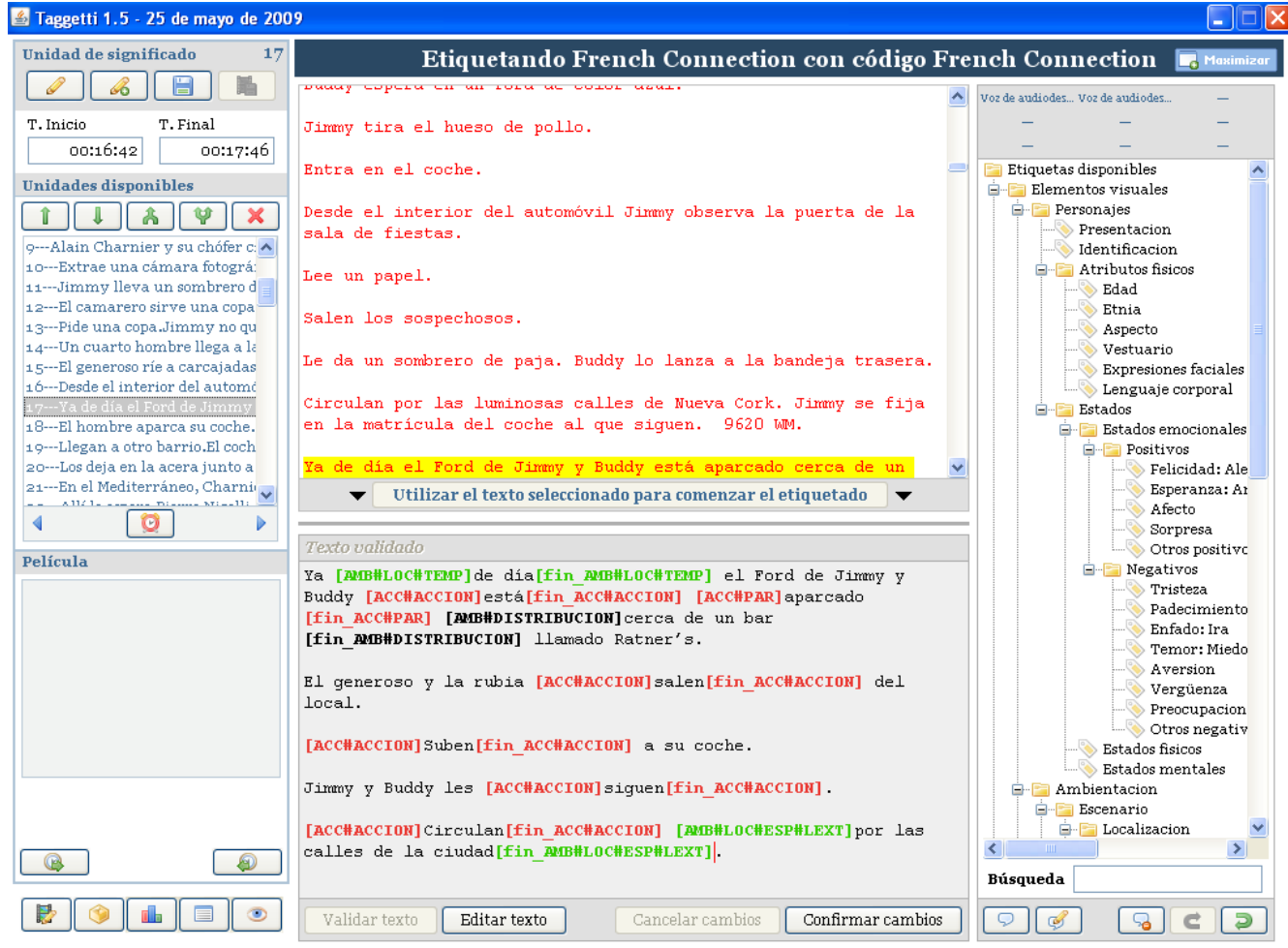

Figure 1. Caption of the Taggetti software used to tagged the audio descriptive script

In these scripts, we find a large number of tropes (they are short of figures) which slide across the AD text, ornamenting them and conferring them a stressed artistic aspect.

We know that the pragmatic dimension of the speech act has to do with Semantics and Syntax as well. The syntax will determine the type of text or discourse we have to examine, as the Spanish Stylists said: "the human being reorganizes the world with the puzzle of the language which is full of metaphors". Consequently, audio describers who are the absolute creators of their text can build the audiodescriptive script peppered by metaphor, metonymy and different tropes, all being considered ornaments of the new rhetorical discourse.

In this sense, we should remember that Rhetoric is essentially pragmatic because it studies the speech act in a certain way: in the middle of a linguistic situation. The AD acts in the same way because it seeks to make the blind person receive the real world described by the audio describer who validates his/her own text based on images, sound, and context recreated in the film. If we write a discourse for a particular auditory/audience we influence them, so that the language we use is important in order to make what we say understood. In addition, the AD is sensitive about building intelligible and correct sentences, but we must know the world which is common to all of us. Finally, the audio describer must know the complex mechanism of cognition which is seeks to make efficient use of the common symbols used by the speaker and the receiver. Thus, the $\mathrm{AD}$ rhetorical discourse will be locutionary, if it transmits some information. Rhetorical discourse is always illocutionary, as well as the audio descriptive text. It is illocutionary, if the sentence is transmitted next to an associated force related to the verbs: order, promise, insult, object, etc. Rhetorical discourse implies the persuasion of the audience who attentively listens to the orator. The audio descriptive text, on the other hand, achieves its function, too, because it uses adjacent verbs to the theme of the audio descriptive script and many of them are verbs oriented to make the text closer to the particular world of the blind person, in the sense that the text influences the blind person, at least persuading him/her and making him/her identified with the reality represented by images that the blind cannot perceive.

Finally, perlocutionary, when the sentence determines some reactions in the audience according to the special circumstances, the rhetorical discourse always has to do with this speech act. However, the audio descriptive text does not, because it depends on the emphasis that the audio describer can give to his/her script and it depends on the speaker's capacity to transmit an important emotional charge to the blind people, who answer the description with different reactions: smiling, crying, shouting, etc. López Eire (2000) says that "Rhetoric is an art which teaches us to create acts of speech that have the force to make the judges absolve or condemn the victim, to make the blind people suffer or enjoy, depending on the emotions they listen to" (p.202).

Rhetoric then studies rhetorical discourse which is a complete, closed linguistic text that results unitary and coherent thanks to its pragmatic meaning which makes it a functional one. It is coherent also because the audio describer thinks of it, structures it, verbalizes it and represents it with a determined and well-defined intention that it is seen in the theme of the discourse, the theme of the discourse being the object of attention of the audio describer when he/she prepares the discourse to be in tune later with the receiver, who is the centre of the emission. 
We might recall that Grice, in his Principle of Cooperation, invites the audience to joint to him in the contemplation of the narrated sequences to evaluate them and to answer to them. His intention was not only for the listener to believe it but as Grice (1989) defends, to be able to feel the things explained from an imaginative and affectionate viewpoint.

\section{Audio Description: A TAutology of SEMiotic AND Rhetoric OF COMMUniCATion}

As mentioned above, Rhetoric is a science of conceptual representations of the statements of discourse because it studies the speech acts that influence the audience due to the message so well prepared by the audio describers.

In this sense, Rhetoric is closely related to the Theory of Communication based in the Theory of Relevance and defending the maximum cognitive effect gained with the minimum effort of processing the act of cognition as a speech act.

We believe that, in the future, Rhetoric must work closely with Pragmatics, which considers communication to be the consciousness of the soul-that is, communication is not only a process of transmission but a selection of information and participation, because communicators select from among all information offered to them. Therefore, "communication is selection, not intention". The AD starts from this premise because despite that the audio descriptive text can move, the main task of the audio describer is to select among all the material he/she has in order to prepare a coherent and thematically cohesive discourse, able to order and clarify human experience.

Thus, we recognize that $\mathrm{AD}$, taken as a sort of modern Rhetoric is very close to social Pragmatics in the best sense, because it implies the study of the speech act, and as Habermas (1973) says "speech and action are interpreted by each other" (p.237) and they never appear separated in the frame of social life.

In fact, the audio describer will centre his/her attention in one or more aspects of the traditional Rhetoric like the dispositio or elocutio and on many occasions in the total process of the Rhetoric phenomenon from a semiotic standpoint. In the sense that Rhetoric is a sort of secondary grammar, a grammar of the devices of the primary rules which make up proper grammar. It is a grammar that contains a system of rules of the persuasive linguistic configuration. It is a grammar of the language created by the orator to target the audience.

Thus, due to the integration of Rhetoric in the Semiotics, the Linguistic of the Text and the Pragmatic, discourse can be successfully analysed with the literary text or the audio descriptive script.

Semiotics or the Science of the Signs of the texts throughout the Linguistic of the Texts runs into Pragmatics, which is the science in the relation to interpreters, because it studies the communicative speech act as such act, the speech as the use of the language by the speaker taking into account the following aspects: the context as the identity of personality of the participants in the act of communication, the spatial and temporal functions, the features in the communicative act, the believes, the knowledge and intention of the audio describers and many other circumstances around the speech act.

\section{Where IS THE AUdio DESCRIPTION INTO THE Linguistic TEXT LOCATED?}

The Linguistic of Text will see in the AD text the result of different operations prepared to localize the external semantic materials (inventio) and the internal ones (dispositio).

In this macro text the coherence results from the intentionality of the author in a single act of speech and the adaptation of the speaker to the communicative situation, expressed in the text as a sum of linguistic signs of great complexity that are used as a framework of syntactic, semantic, and semiotic relations.

\begin{tabular}{|l|l|l|}
\hline RHETORIC & PRAGMATIC OF TEXT & AD SCRIPT \\
\hline Inventio & Extensional material (ideas used) & Units of meanings (Taggetti) \\
\hline Dispositio & Macro intentional Structures & Statements (Taggetti) \\
\hline Elocutio & Micro intentional Structures & Sentences (Taggetti) \\
\hline
\end{tabular}

Figure 2. Table of representation of these linguistic signs

Dispositio is responsible for the coherence of the rhetorical discourse in all dimensions and it results from the adaptation of the whole Rhetoric discourse and, from each of the constitutive elements and resources that unleashes in the audio describer the determination of intervention to modify the previous situation. The opportunity is a concept from the Medicine in the Athens of $5^{\text {th }}$ century B.C., and it is understood as the principle which guides the process of preparation and the deliver of the rhetoric speech because it determines the inventio (ideas to express), the dispositio (order of these ideas) and the elocutio (expression of the ideas).

If the audio describer does not connect with the audience because his/her discourse fails, the opportunity of the discourse must be valued, the adaptation to the place, the moment, the mentality and the particular vision of the world that the blind people have.

We should not forget that to compose a successful text, we need two prior conditions: the first is to complete levels of form and content and the second is to attain the perfection of the text as well as the level of action at which the

\footnotetext{
${ }^{2}$ Niklas Luhman (1984). Soziale System. Grundriss einer allgemeinen Theorie: Frankfurt.
} 
linguistic use is controlled. A good rhetorical discourse has well-adapted syntax to create a coherent and functional text with a great success in the communication.

\section{QUINTILIAN RHETORIC AND AUDIO DESCRIPTIVE TEXT}

As it is known, text is not the same thing as discourse. Text is any written piece with an explicit typographic limit, but the discourse is the result of the integration of the text, the voice, the gestures inserted into the framework of the rhetorical communicative act as a phenomenon ${ }^{3}$. In this sense, the text itself will be understood as a discursive rhetorical text in the Quintilian sense due to the five different phases of rhetorical discourse: invention, disposition, elocution, memory, and action.

We should remember that inventio is a complex rhetoric operation consisting of a method of discovering materials that prove the cause invented by the orator. Inventio is the first rhetoric operation ${ }^{4}$ to obtain a good interpretation through the discourse, as Pujante (2003) argues is "the adventure of building a discourse is the adventure of interpreting a part of the world" (p.13), of making a meaning or a corpus of units of meanings, as the units organized by the audio describer in his/her text.

Steiner thought that rhetorical discourse created structures of values, meanings, and suppositions ${ }^{5}$.

The second rhetoric operation studied by Quintilian is the dispositio, which consists of the presentation of the facts as we think they have occurred. It is the view of the past, the future or the present regarding certain facts. When we are studying, the facts described are the most effective indicators of this rhetorical operation. Cicero ${ }^{6}$ pointed out three types of narration: i) description of the state of things, ii) an external digression from the cause, is a narration into the narration (when we narrate an example), and iii), the literary narration that contains the fibula, the story and the fiction.

Thus, the AD can lie within the limits of the type i) of Ciceronian narration, but using the other types also (e.g. when the audio describer uses the cinematographic techniques of flashback, etc.) ${ }^{7}$.

With the dispositio, we realize that the discursive materials must be described within distinct limits by the three narrative virtues: clarity, shortness, and likeliness. With clarity, we make the narration completely comprehensible to a blind person. With shortness, we omit every superfluous thing, and, with the likeliness, we make all the narrative facts coherent in the total narration.

In summary, during the rhetorical act something occurs on two different levels: the level of expression and the level of the narrative structure (dispositio and elocutio, respectively). Today, theoretical studies have recovered the relationship between the meaning and the structure of the narrative elements: when a tale or a novel is understood as a complex sign and it is studied as the integration of the different levels to build complex meanings.

The importance of the dispositio is manifested in two versions: 1) the modern reflection on the narrative structures based on the disposition in res (thematic organization) and verba (narrative structures) and 2) the reflections that are born from it. The dispositio opens the way to the inventio, so that the audio describer must be able to be an intelligent man delivered with all his forces to the "disembowel of the confusing cause" as Pujante argues (2003). This observation should be directed to the looking for the materials and the order of the significant construction of all of them.

With the elocutio the facts created in the mind by the audio describer are expressed. Thus, the thoughts are stated with accuracy. During this phase the audio describer realizes that the expressive virtues: purity, clarity and ornamentation must always be fulfilled. Purity is a grammatical virtue. The objective of clarity is to be understood. And embellishment is to ornament the discourse thanks to the tropes of figures of diction or thoughts.

The memory is the $4^{\text {th }}$ Quintilian operation but it may take into account only in the AD of the Theatre, and not always. The audio describer needs to sharpen his/her perception of the referential world to express it in the AD script. In this sense, he/she must to know previously in the performance any single signs, words or gestures, in case he/she has to improvise and remind the actors of what they forget.

And finally, the Actio is determined by the own reception of the Rhetoric discourse or the AD text by the blind audience.

\section{TROPES AND FIGURES IN THE AUDIO DESCRIPTIVE SCRIPT}

The audio describer, as creator of the audio Rhetoric discourse must be able to distinguish between tropes and figures, knowing that the trope represents a mutation, a translation of meaning but not in the figure, because the figure consists on the full form of a sentence or thought, in a reasonable change, a change in the words or in the sense, depending on the manner of speaking.

\footnotetext{
${ }^{3}$ The definition we use for discourse is taken from David Pujante's Theory of Rhetoric because we consider it the most appropriate for our definition of a rhetoric AD text (Pujante, D. (2003). Manual de Retórica. Castalia Universidad: Madrid).

${ }^{4}$ The Quintilian Rhetoric operations are: inventio, dispositio, elocutio, memoria and actio.

${ }^{5}$ Steiner, G. (1998). Errata. Madrid: Siruela: 13.

${ }^{6}$ Cicerón, M.T. (1976). De Inventione. London-Cambridge U.P.

${ }^{7}$ In the AD script of the Spanish film Del rosa al amarillo, we find the case of the William, the main character of the film when he dreams about the First World War. Or in the case of the film Citizen Kane, when the main character remembers his childhood, and the AD script uses the technique of the flashback to describe it.
} 
Quintilian distinguished the tropes depending on their meaning or depending on the way of expressing their ornamentation of the text. He studied some tropes such as the metaphor, metonymy, synecdoche, antonomasia, irony, periphrasis, hyperbole, emphasis and litotes. In this paper, we realized that they appeared in some of the AD scripts tagged by the software TAGGETTI. Therefore, we have discovered that the tropes are the usual elements of ornamentation use by the audio describer in his AD text. Let us see some examples from different films shown by the Spanish National Organization of the Blind People (ONCE) that works with us in the Project AMATRA. In this sense, we will offer firstly the definition of the tropes from a Dictionary of literary terms ${ }^{8}$ and, secondly some examples of six tagged script where we have found these tropes.

Metaphor

Cuddon (1986) defines metaphor as "a figure of speech in which one thing is described in terms of another. It is the basic figure in poetry. A comparison is usually implicit; whereas in simile it is explicit" (p.391).

Examples of metaphors in the AD script of the Spanish film Del rosa al Amarillo ${ }^{9}$ :

(1) William wakes up with the First World War on the Russian Snowed Steppe, German soldiers attack under a rain of bombs.

Metonymy

Cuddon (1986) defines metonymy as "a figure of speech in which the name of an attribute or a thing is substituted for the thing itself. Common examples are 'The Stage' for the theatrical profession; 'The Crown' for the monarchy” (p.394).

Examples of metonymy in the AD script of the film French Connection ${ }^{10}$ :

(2) The Lincoln is parked next to him.

From the same script:

(3) In the morning Jimmy and Budd's Ford is parked near a bar called Ratner's.

Synecdoche

Cuddon (1986) defines synecdoche as "a figure of speech in which the part stands for the whole, as thus something else is understood within the thing mentioned" (p.676).

Examples of synecdoche in the AD script of the film Ben Hur ${ }^{11}$ :

(5) Ben Hur came near the rest.

(6) He overtakes the sixth.

Antonomasia

Cuddon (1986) defines antonomasia as "a figure of speech in which an epithet, or the name of an office or dignity is substituted for a proper name" (p.50).

Examples of antonomasia in the AD script of the film Ben Hur:

(7) The Caid asks the Roman for patience.

(8) Mesala brings the knives closer to the Corinthian wheel.

Irony

Cuddon (1986) says that irony 'In Plato's Republic where it has approximately the meaning of 'a glib' and underhand way of taking people in (...)” (p.335).

Examples of irony in the AD script of the film Del rosa al amarillo:

(9) There is a section of Spanish soldiers of the Blue Division with them who attacks in a chaotic way producing surrealist images, it was almost a joke.

\section{Periphrasis}

Cuddon (1986) defines periphrasis as "a roundabout way of speaking or writing; known also as circumlocution; thus, using many or very long words where a few or simple words will do" (p.500).

Examples of periphrasis in the AD script of the film Chariots of fire ${ }^{12}$ :

(10) Eric gives a gift to a boy. Eric is sitting in front of a table. Next to him his family and the chancellor are sitting. He looks at a man next to him.

\section{Hyperbole}

Cuddon (1986) defines hyperbole as "a figure of speech which contains an exaggeration for emphasis" (p.316).

Examples of hyperbole in the AD script of the film Del rosa al amarillo:

(11) There is a soldier who attacks with an open umbrella to support the rain.

Emphasis

Cuddon (1986) defines emphasis as a "stress laid on a word or words to indicate special meaning or importance" (p.461).

Examples of Emphasis in the AD script of the film Del rosa al amarillo:

(12) The screen turns in pink colour. From a heart appears the image that makes William to dream: Margaret and he were walking down the beach.

\footnotetext{
${ }^{8}$ Cuddon, J.A. 1986. A Dictionary of Literary Terms. London: Penguin Book.

${ }^{9}$ Del rosa al amarillo (Manuel Summers, 1963; AD: Javier Navarrete, 1998).

${ }^{10}$ French Connection (William Friedkin, 1971; AD: José Antonio Álvarez, 2003).

${ }^{11}$ Ben Hur (William Wyler, 1985; AD Antonio Vázquez, 2008).

${ }^{12}$ Chariots of fire (Hugo Hudson, 1981; AD: José Antonio Álvarez, 2005).
} 


\section{Litotes}

Cuddon (1986) defines litotes as "a figure of speech which contains an understatement for emphasis, and is therefore the opposite of hyperbole. Often used in everyday speech (frequently with a negative assertion) and usually with laconic or ironic intentions. A stock instance is 'not bad' meaning 'very good' (p.366).

Examples of litotes in the AD script of the film Chariots of Fire:

(13) Eric runs quickly and he maintains the distance from his rivals. Nobody can catch him. He runs straight to the end.

At this point in the discourse created by the audio describer we find many examples of ornamentation by the tropes. The figures of diction and thought can be elements of ornamenting a rhetoric text, but in the case of the AD they do not appear so frequently. The figure in his literate sense is a form (of the body), and in this case is an expressive form, the oral one. In the traditional Rhetoric the figures were known as schema, which consists in a reasonable change of the meaning or the words from the vulgar mode to a simple one. The figures are: figures of diction, that affect the linguistic expression (schemata) and figures of thought. All are grammatical figures and they consist of morphological and syntactic devices, as the rhetoric figures which are figures of words but with a different grammatical device. But the repetition, the rest of the figures of diction or thought do not appear in the AD discourse.

\section{CONCLUSIONS}

The audio descriptive text can be and should be considered (in our opinion) to be modern rhetoric discourse, a coherent oral text and at the same time a functional act of speech. Giving some examples of the traditional Rhetoric and comparing them with the audio descriptive scripts, we find that four of the Quintilian rhetorical phases appear in the AD discourse as well. Thus, the audio describer using them in a script can draw the blind audience closer to the artistic text, which is intended to be a cohesive and coherent multimodal oral discourse in a rhetorical way.

\section{REFERENCES}

[1] Alabaladejo, T. (1998). Quintiliano: Historia y Actualidad de la retórica. Vol. III. Logroño: Ediciones de Estudios riojanos.

[2] Álvarez de Morales, C. (2010). Un nuevo sistema de modelización secundario: la AD en la narración fílmica. Un corpus de cine. Teoría y práctica de la audiodescripción. Granada: Tragacanto, 181-204.

[3] Austin, J .L. (1962). Palabras y acciones. Buenos Aires: Losada.

[4] Austin. J. L. (1981). Cómo hacer cosas con palabras. Barcelona: Paidós.

[5] Barthes, R. (1970). Retórica de la imagen. La Semilogía. Buenos Aires: Tiempo Contemporáneo.

[6] Cattani, A. (2003). Los usos de la Retórica. Madrid: Alianza.

[7] Cicerón, M. T. (1976). De Inventione. London- Cambridge U.P.

[8] Cuddon, J. A. (1986). A Dictionary of Literary Terms. London: Penguin Book.

[9] De Man, P. (1984). The Rhetoric of Romanticism. Columbia: U.P.

[10] Díaz Cintas, J. (2008). The Didactics of Audiovisual Translation. Amsterdam: John Benjamins

[11] Dijk, T. A. (1983). La estructura retórica del texto. La ciencia del texto. Barcelona: Paidós Comunicación.

[12] Gambier, I. (2001). (Multi) Media Translation. Concepts, Practice and Research. Philadelphia: John Benjamins.

[13] Grice, P. (1989). Studies in the Ways of Words. Cambridge: Cambridge U.P.

[14] Gutiérrez San Miguel, B. (2006). Teoría de la narración audiovisual. Madrid: Cátedra.

[15] Jiménez, C. (2010). Un corpus de cine. Fundamentos teóricos de la audiodescripción. Un corpus de cine. Teoría y práctica de la audiodescripción. Granada: Tragacanto, 13-56.

[16] Habermas, J. (1981). Teoría de la comunicación. Frankfurt. Vol II.

[17] Lausberg, H. (1975). Elementos de retórica literaria. Madrid: Gredos.

[18] López Eire, A. (2000). Esencia y objeto de la retórica. Salamanca: Ediciones Universidad de Salamanca.

[19] Luhman, N. (1989). Soziale Systeme. Grundriss einer allgemeinen Theorie: Frankfurt.

[20] Michelstaedter et all. (2009). La persuasión y la Retórica. Madrid: Sexto Piso.

[21] Orero, P. (2004). Topics in Audiovisual Translation. Filadelfia: John Benjamins.

[22] Oxford English Reference Dictionary, (1996).

[23] Platón. (1972). Obras completas. Madrid: Aguilar.

[24] Pujante, D. (2003). Manual de retórica. Madrid: Castalia.

[25] Quintiliano, M. F. (1992). Quintiliani Institutionis Oratoriae Libri I-II. Oxford.

[26] Salway, A. (2007). A corpus based analysis of the language of audio description. In Díaz Cintas, J., Orero y A. Remael (eds). Proceedings Media for All. Accesibility in Audiovisual Translation. Amsterdam: Rodopi, 151-174.

[27] Steiner, G. (1998). Errata. Madrid: Siruela.

[28] Wilkins, A. S. (1964). M. Tulli Ciceronis Rhetorica. Vol. II. Oxford: Oxford U.P. 


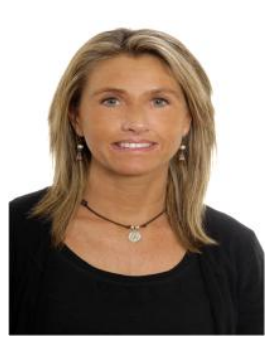

Cristina Álvarez de Morales was born in Granada (Spain) in 1970. Graduate in Spanish Language and Literature from the University of Granada (Spain) (1993). Graduate in the English Language and Literature from the University of Granada (Spain) (2006). Doctor in Theory of Literary and General Linguistics from the University of Granada (Spain) (1997).

She has been LECTURER at the University of Vigo (Spain) at the Department of Translation and Criticism (1999-2000). She also has been TEACHER of The Secondary School Lux Mundi in Granada (Spain) (2004-2008). And she is now LECTURER at the University of Granada (Spain) at the Department of Translation and Interpretation (2008-). She is the author of Aproximación a la teoría poética de Harold Bloom, Granada: University of Granada (1996). Harold Bloom y sus Teorías. Granada: University of Granada (1998), and "Un nuevo sistema de modelización secundario: la audiodescripción en la narración fílmica”. Un corpus de cine. Teoría y práctica de la audiodescripción. Granada: Tragacanto (2010), 181-204.

Dr. Álvarez de Morales is member of the Spanish Society of Literary Criticism (AECL). And she received the Graduation Honorary Award from the Andalusian Government (1998). 